\title{
Local power: exploring the motivations of mayors and key success factors for local municipalities to go $100 \%$ renewable energy
}

Henner Busch ${ }^{1 *}$ and Kes McCormick ${ }^{2}$

\begin{abstract}
Background: This paper investigates the decision-making processes of mayors on the municipal level in Brandenburg, Germany, to support 100\% renewable energy policies as well as the respective key success factors. Three different cases and their specific settings are examined: (1) Turnow-Preilack with Germany's largest solar power plant, (2) Prenzlau, a town claiming the title 'City of Renewable Energy' and (3) the village of Feldheim, the first energy independent settlement in Germany.

Methods: On the basis of exploratory site visits and interviews, the process of implementation of renewable energy is investigated. The methodology developed here is based on the 'theory of planned behaviour' which helps to visualise the individual decision-making processes of key actors.

Results: Not surprisingly, many different factors influence the investigated cases. The decision-making processes must be investigated in their context that is shaped by the attitudes of mayors, the expectation of how their actions will be perceived, and the control mayors estimate to have over projects.

Conclusion: The identified factors point at the key finding that the mayors first and foremost think about the 'good of their municipality'. This does not necessarily refer to economic factors but can encompass aspects such as 'strengthening community life'. More abstract factors such as climate change or contributing to the transition of the national power supply play - if at all - a minor role. Policies that aim at supporting energy transitions in similar settings should therefore shift their focus from communicating climate change mitigation to the co-benefits that ambitious renewable energy policies can bring to a community.
\end{abstract}

Keywords: Renewable energy; Sustainable development; Local municipalities; Climate change; Energy policies; Local environmental governance

\section{Introduction}

There are increasing discussions and calls for shifting towards $100 \%$ renewable energy [1-4]. The German Federal Government has committed to $80 \%$ of electricity from renewable energy by 2050 and consequently Germany's energy system is in transition [5] (see Figure 1). The German 'Energiewende' or energy transition is widely recognized as a leading approach for initiating a significant increase in renewable energy at national, regional, and local levels. The German Advisory

\footnotetext{
* Correspondence: henner.busch@lucsus.lu.se

${ }^{1}$ Lund University Centre for Sustainability Studies (LUCSUS), P.O. Box 170, 22100 Lund, Sweden

Full list of author information is available at the end of the article
}

Council on the Environment - a scientific council that advises the German Federal Government - comes to the conclusion that a transition to $100 \%$ renewable energy in Germany is not only possible but also secure and affordable [5].

Throughout Germany, many municipalities are contributing to the German Energiewende. The German Competence Network for Distributed Energy Technologies lists more than 120 municipalities that have committed to reaching $100 \%$ renewable energy [6]. Approximately 50 municipalities have already reached this goal by early 2012 [7]. This characteristic is shared despite socio-economic, geophysical and strategic heterogeneity. At the same time a geographical clustering of these administrative authorities 


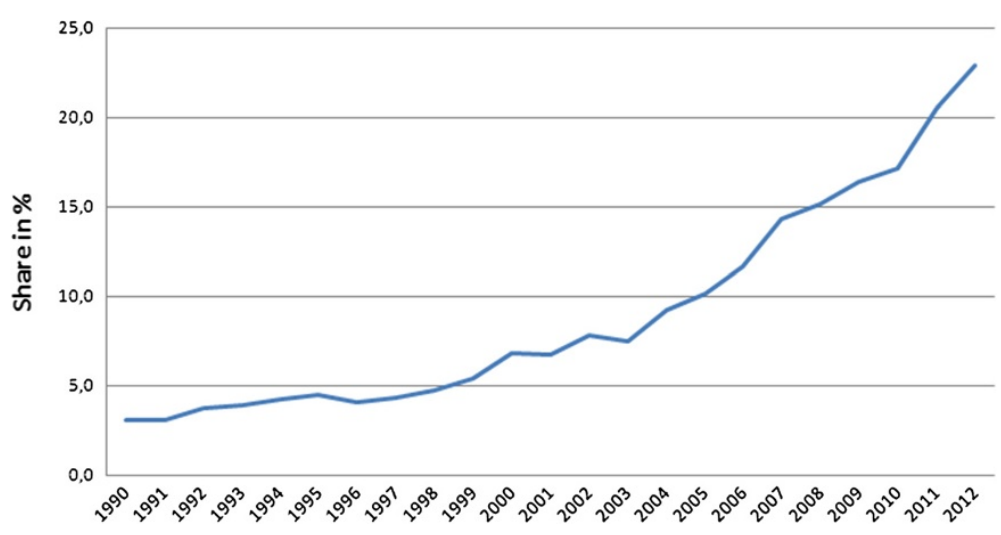

Figure 1 Share of renewable energy in Germany. Source: Federal Ministry for the Environment, Nature Conversation and Nuclear Safety.

cannot be observed [8]. These two findings lead to the assumption that it is not structural preconditions (e.g. judicial framework) or special regional potentials (e.g. physical conditions) that have led to the occurrence of these cases.

In the light of these observations, it can be assumed that the explanation for the occurrence of these ideal cases' can be found within the municipalities. This assumption is even more reasonable when taking a closer look at the municipal level. While in the European Union, national or regional programmes often aim at producing favourable conditions for renewable energy, the decisions and actions for the infrastructure takes place at the local level. Furthermore, Wüste and Schmuck [7] point out that in many cases, municipal mayors are heavily engaged in the transition process. As local leaders, they become important because in many cases, social aspects play a decisive role when an energy system is substantially modified [9]. Consequently, this paper has a strong focus on social and political aspects without neglecting technical factors.

Focusing on the introduction of renewable energy technologies at the local level, this paper investigates three municipalities in the German Federal State of Brandenburg (see Figure 2), which has committed to $100 \%$ renewable energy by 2030. The key question this paper addresses is 'Why do mayors support the introduction of renewable energy and what are the key success factors for $100 \%$ renewable energy policies?'. The three 'success stories' of Prenzlau, Feldheim (in the municipality of Treuenbrietzen) and Turnow-Preilack are analysed. The cases are characterized by either producing significant amounts of renewable energy or harbouring outstanding initiatives and projects. On the basis of field visits and face-to-face interviews, the individual motivations of mayors and the key success factors that underpin commitments to renewable energy are explored and categorized.
In the literature on local environmental governance in general, the importance of multi-level governance (covering international, national and local levels) and collaboration between multi-sector actors is stressed (cf. [10-15]). Due to political, social and technical linkages in the field of renewable energy interactions over different scales are particularly relevant [16-19]. Investigations of local energy transitions point at the complexity of these transitions $[9,20]$. However, the decision-making processes at the local level behind ambitious renewable energy policies, and particularly the role of mayors, has not been investigated in detail. This paper argues that mayors play a pivotal role in transitions to $100 \%$ renewable energy (particularly in small municipalities) through building support, brokering deals, communicating visions and ensuring the implementation of projects. It is important to place the motivations and behaviours of mayors in a local context, and this paper therefore connects the role of mayors with key success factors for renewable energy policies. This paper hopes to contribute to the local environmental governance literature through deeply exploring the role of mayors in realising $100 \%$ renewable energy in local municipalities. By concentrating on the decision-making processes of mayors, we hope to unveil drivers for individual decisions in favour of energy transitions. Identifying drivers can be a valuable complement to existing literature which tends to focus on barriers of local energy transitions (cf. [21-23]).

\section{Cases}

This research is based on three case studies in Brandenburg, Germany (see Table 1). These cases differ in regards to area, population size and types of renewable energy projects. Furthermore, differences can be found in the implementation processes for renewable energy projects. The first case, Turnow-Preilack, holds special relevance because Germany's largest solar power plant can be found 


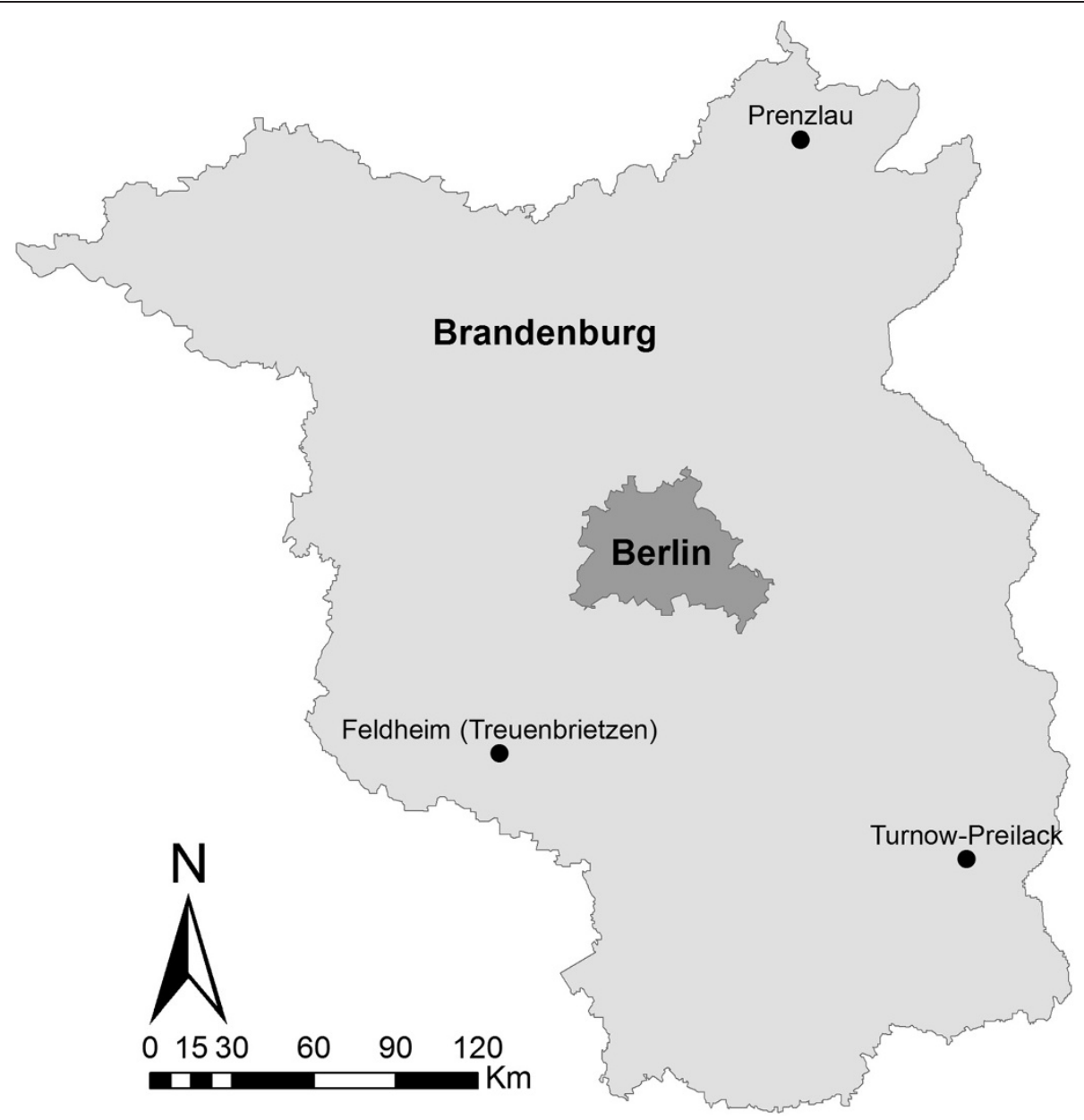

Figure 2 Location of case studies in Germany.

here. The Lieberose Solar Power Plant had an initial capacity of $52 \mathrm{MW}_{\text {peak }}$ in 2009 which was expanded to 71 $\mathrm{MW}_{\text {peak }}$ in 2011. The electricity is fed into the grid at the point of delivery belonging to the Jänschwalde Power Plant (which is in fact the largest coal-fired power station in Germany with an installed capacity of 3,000 MW). Overall, $160 \mathrm{M} €$ was invested in the first phase until 2009 by the owner. Besides the solar power plant, a biogas plant and two wind turbines can be found within the municipality's borders. The biogas plant is supplied by a pig farm where the produced heat is consumed. The wind turbines feed into the national grid. All three installations are privately owned.

The case of Prenzlau is of special interest because Prenzlau - through the 'Stadtwerke' (municipal energy supplier) - on the one hand, invests into the production of energy from 'conventional' renewable sources. On the other hand, Prenzlau - in cooperation with the company ENERTRAG - works as a laboratory in the field of renewable energy. The biennial energy fair of Prenzlau (called 'Prenzlauer Energie Messe') offers a forum for different actors in the field of renewable energy to present their companies, products or cases (established in 2003). The 'Lange Nacht der Erneuerbaren Energien' (translated as the night of renewable energy) was initially held in 2010 and it is dedicated to bring together companies and citizens interested in renewable energy. All these activities support the claim by Prenzlau to be the 'City of Renewable Energy' in Germany (or 'Stadt der Erneuerbaren Energien'). In Prenzlau, a number of different renewable energy applications can be found. While the municipality-owned power supplier runs a biogas plant, geothermal electricity and heat generators, and several solar installations, the local energy company called ENERTRAG runs 440 wind turbines across Germany (of which 48 have a maximum capacity of 49 $\mathrm{MW}_{\text {peak }}$ and an investment of nearly $80 \mathrm{M} €$ are within the administrative borders of Prenzlau). ENERTRAG also constructed a wind-hydrogen power plant where during times of cheap energy prices, electricity is converted into hydrogen. During peak hours, the hydrogen is fed to a block heat and power plant. 
Table 1 Background of case studies

\begin{tabular}{llll}
\hline Location & Inhabitants & Installations & Mayor \\
\hline Turnow-Preilack & 1,233 & $\begin{array}{l}\text { Solar power plant } \\
\text { (700,000 solar panels) }\end{array}$ & Mr. Fries \\
& & Wind turbines (2) & \\
& & Biogas plant & \\
& & Biogas plant & Mr. Sommer \\
Prenzlau & 20,285 & Geothermal heat and & \\
& & electricity generators & \\
& & Solar installations & \\
& & Wind turbines (48) & \\
& & Wind-hydrogen power \\
& & & \\
& & plan & \\
& & Biogas plant (heat and & Mr. Knape \\
Feldheim & & electricity) & \\
& & Wind turbines (43) & \\
\hline
\end{tabular}

The village of Feldheim is located in the municipality of Treuenbrietzen. Feldheim is the home of 221 people. Despite the low number of inhabitants, the village of Feldheim is of great importance for the whole energy system in Germany. This is because Feldheim is the first settlement in Germany that has achieved energy independence. The local energy company, called Feldheim Energie, supplies nearly all households with electricity as well as heat for warm water and heating purposes, which is produced in a biogas power plant. In terms of electricity, the biogas plant provides $500 \mathrm{~kW}_{\text {peak. }}$. There are also 43 wind turbines at a wind farm near the village producing $74 \mathrm{MW}_{\text {peak }}$ and feeding electricity into the national grid. What makes the case even more special is the fact that not only the energy-producing infrastructure but also the grids of the village belong to Feldheim Energie. It is a local enterprise that is owned by the municipality, companies involved in the local energy transition and the inhabitants of Feldheim.

\section{Methods}

As mentioned before, this research involved three case studies located in Brandenburg, Germany. This region was selected because of the large utilisation of renewable energy and the remaining significant potentials. Investigating three case studies within the same region also provided some similarity in regards to socio-economic factors. The three case studies focus on heat and electricity from renewable energy sources. There is no exploration of the transport sector or energy efficiency measures. However, these activities are often closely interrelated with renewable energy projects.

\section{Sampling}

We applied purposive sampling to select the three cases. Due to the exploratory character of the study and the resulting inductive interaction between theory and empirical material, the sampling was not a form of theoretical sampling as defined by Silverman [24]. All cases were sampled as 'success cases' prior to field work. The assessment of success of these municipalities was based on a literature review of scientific literature, analysis of 'grey' literature, internet research and initial interviews with persons knowledgeable in the field and the Brandenburg region. These initial interviews were conducted with three consultants from private companies that work in this field and four employees at public bodies (Brandenburg Economic Development Board, two at Brandenburg Ministry for the Environment, and the regional energy agency). This search for success cases is in line with the sampling approach of 'extreme cases' by Flyvbjerg ([25], p.306), who argues that choosing extreme cases is valid if the research aims to develop new concepts, variables, and theories' ([25], p.307). The conscious decision to search for extreme cases has negative implications on the generalizability of findings. Nevertheless, the identified variables (the different motivational reasons and success factors) do not only help to understand the investigated cases but can become the starting point for similar investigation of other cases.

The research methods included a literature review, expert and stakeholder interviews, and field visits. All interviews were conducted face-to-face at the respective work places of the informants or during field visits. The interviews were taped and then later coded. In total, 14 interviews were conducted with municipal staff and mayors as well as experts in the field of renewable energy in Germany. Of these 14 interviews, 11 were conducted with people directly involved in the cases (Turnow-Preilack (3), Feldheim (4) and Prenzlau (4)). Interviewees were the three mayors, staff members from the municipalities and representatives from each of the companies that are involved in the projects. The remaining three interviews were conducted with two consultants that were involved in the cases and one researcher from the Brandenburg University of Technologies. During the field visits, more informal conversations were held at further occasions, including during shared meals, drives to field visits and outdoors at the project sites. The information gathered in these informal conversations as well as the impressions from the site visits were secured in field notes. These informal processes can be called 'narrative walks', which are a way of engaging in exploratory research [26]. Here, a researcher can get in close contact with the object of study. It is furthermore a chance to speak to informants outside of the - sometimes intimidating - atmosphere of a formal interview. In addition, the researcher can gain access to the daily life of people and their occupation. While the interviews with the mayors were used to identify their motivations for 
engaging in renewable energy, the other interviews and field visits were needed to identify the success factors and structural conditions around the decision-making processes for $100 \%$ renewable energy.

\section{Theoretical basis}

As a theoretical basis for this research, the 'theory of planned behaviour' developed by Ajzen was employed $[27,28]$. At first glimpse, the theory of planned behaviour on the one hand gives an adequate frame of reference by serving as a tool to 'map' the respective decision-making processes. On the other hand, it serves as a kind of 'blank standard form' that can be filled in with findings from a specific context. While explaining the occurrence of behaviour, it leaves enough space for the adjustment of the theory to specific situations [28]. The theory of planned behaviour was used to reconstruct the decisionmaking processes of three mayors during the initial phase of renewable energy projects within the three case studies. The theory of planned behaviour helps to categorize and visualise the reasoning behind complex decision-making processes (see Figure 3).

In the context of the theory of planned behaviour, 'Attitude' is defined as 'the degree to which a person has a favourable or unfavourable evaluation or appraisal of the behaviour in question' ([28], p.188). 'Subjective norm' refers to 'the person's perception of social pressure to perform or not to perform the behaviour under consideration' ([27], p.117). 'Perceived behavioural control' is defined as 'the perceived ease or difficulty of performing the behaviour and it is assumed to reflect past experience as well as anticipated impediments and obstacles' ([28], p.188). All three aspects influence the 'intention' of a person. This intention indicates 'how hard people are willing to try' or 'how much of an effort they are planning to exert' ([28], p.181). There are two links from the perceived behavioural control. The first link (to intention) stands for a person's estimation of the chances to succeed. Ajzen introduced the second link (to behaviour) because the perceived behavioural control can be seen as an actual measure for the chances of success [28]. Ajzen claims that the second link was constructed on the basis of experimental data [28]. However, the second link does not influence this study as the focus is on the processes that take place before behaviour is actually performed.

Originating from behavioural science the theory has seen some criticism over the course of the last two decades (cf. $[29,30])$. The main criticism has been that the theory lacked the influence of emotional factors and that the theory could only be to a limited degree of predicted future behaviour. Despite this criticism, the theory has proven its value through application in a wide range of different disciplines during its more than 20 years of existence. Several examples can be found where the theory of planned behaviour was employed in the context of environmental related behaviour (cf. [31-34]). While we acknowledge the criticism of the theory, we still consider the approach useful in the context of this paper. We applied the theory less for its explanatory value and its contribution to behavioural science but for its use as a mapping, categorisation and visualisation tool. The theory thus is used more as an analytical framework or sensitising concept [35] in this paper.

\section{Results}

In this section, the analysis of each case is structured with an account of the transition processes in the municipality, the advantages and drivers for the transition are analysed, and finally, structural conditions that define the possible scope of action for mayors are depicted.

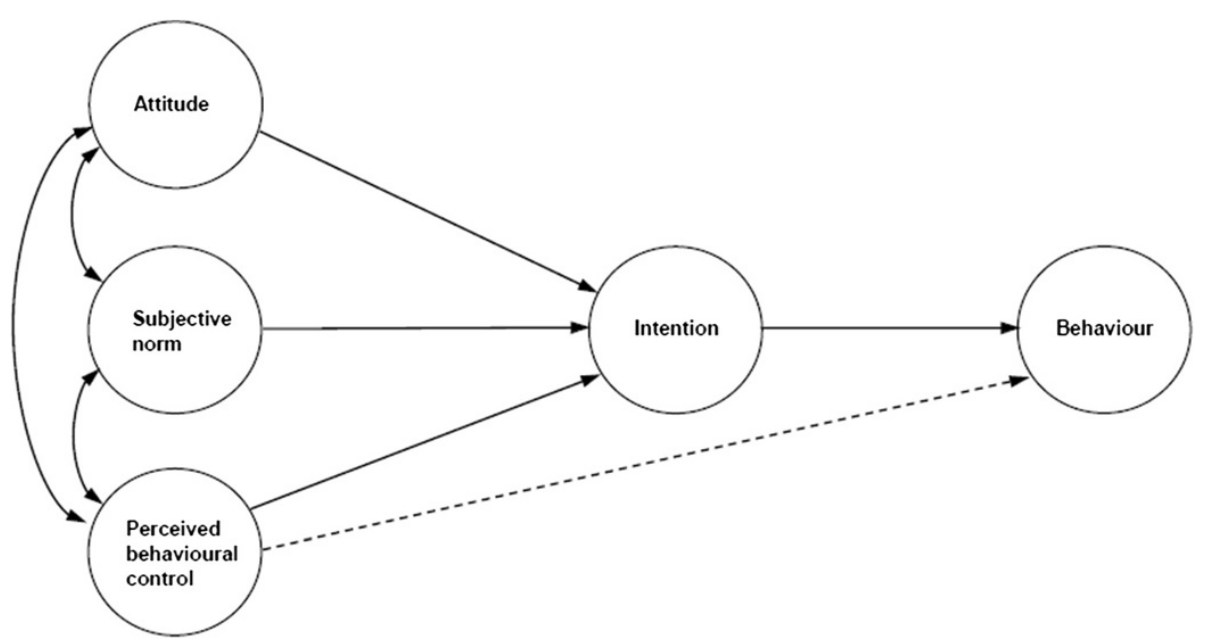

Figure 3 Theory of planned behaviour. Source: [28]. 


\section{Case 1: Turnow-Preilack}

In the case of Turnow-Preilack, the process of implementing the project took place in a very short time. However, this does not make the process less complex. According to Mr. Fries, it became known that the ground water in Turnow-Preilack was heavily contaminated. The contamination was traced back to the former military training ground partly lying within the municipality borders. At the same time, the project developer Procon searched the central register of Brandenburg for suitable areas to construct a large solar power plant. Former military training grounds were especially interesting, since special subsidies by the Federal Government were available for such projects. The former military training ground 'Lieberose' was chosen. Parts of this area are within the borders of Turnow-Preilack. Most of the area is forested nowadays.

The investors (Juwisolar, a company in the sector of renewable energy, and First Solar, a producer of photovoltaic panels) had the solar panels and the capital ready so the project agency pushed for a quick start. Federal law states the municipality has to provide a development plan for projects to be implemented. According to Mr. Fries, a deal was struck that municipality would provide the development plan within 8 months, while the project agency would convince the investors to advance the due tenure for the area to finance the decontamination of the soil under the solar power plant. The plan was developed within the set time period and the installation of solar panels started as agreed [36]. The communication with higher administrations was exceptionally smooth.

For Mr. Fries, the advantages of the solar power plant were obvious: The initial incentive was the decontamination of the soil at the project site. Positive effects occurred during the construction phase when up to 100 workers were employed at the site. These workers found food and accommodation in the nearby villages of Turnow and Preilack. Furthermore, a protected nature area was installed around the plant. Surprisingly, the character of the constructed plant seems to have not played any role in the decision-making process of the municipality. Mr. Fries stated 'Climate change or the depletion of fossil fuels did not play a role in the decision-making process.' However, some statements show that in the ex-post evaluation, positive environmental aspects of renewable energy were identified: 'Over there, you can see the exhaust from the Jänschwalde power plant. That's the dirty energy and here you can see the clean energy.' This was a comment by Mr. Fries while on a viewpoint close to the solar power plant.

Without any intention to play down the work of the mayor and the municipal council, it must be said that internal motivations did not drive the initial implementation of renewable energy; instead, it was externally shaped structures. The match between the needs of the municipality, namely the decontamination of the military training site and the project developer seems to have been purely coincidental. However, when it became obvious that a unique win-win situation was not to be missed, all involved actors joined forces. An additional structural factor was the available subsidies for former military training grounds which have been labelled as a 'conversion area' (see Figure 4).

\section{Case 2: Prenzlau}

The situation in Prenzlau was entirely different. Here, the process took much longer and can be traced back to the 1980s. In addition to that, many different key actors can be identified who - over several years - contributed to the development of renewable energy in Prenzlau.

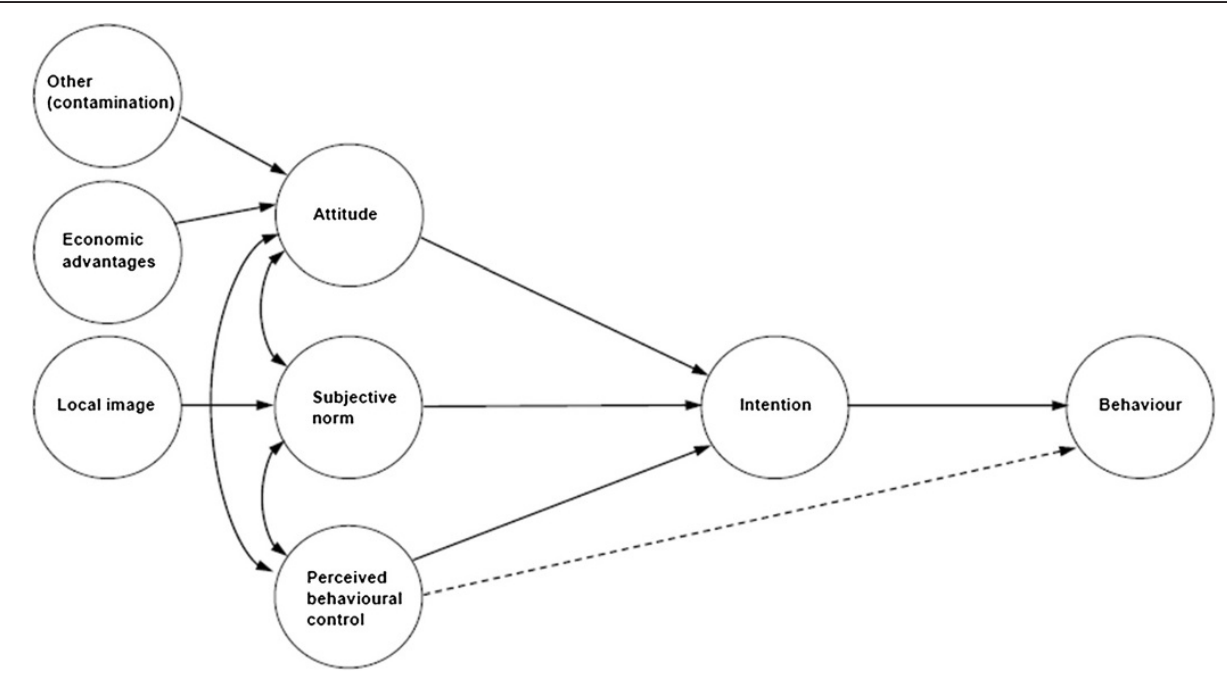

Figure 4 Theory of planned behaviour for Mr. Fries. 
Besides the city administration, three main companies must be named: (1) the city-owned 'Stadtwerke Prenzlau' (the regional power supplier), (2) ENERTERAG (a consultancy for renewable energy projects, mainly wind power) and (3) Aleo Solar (a solar panel manufacturer). The three companies own several renewable energy installations in the city or its vicinity. While the Stadtwerke Prenzlau runs the geothermal heat production, a biogas plant and number of solar panels, ENERTRAG owns 48 wind turbines close to Prenzlau and Aleo Solar runs a factory for solar panels. According to Mr. Sommer, the development was possible because of a few active key actors and some special structural factors. Mr. Sommer stated, 'The founder of Aleo Solar was a business man who originated from Prenzlau. When he returned with some capital, he decided to give something back to his hometown. So he founded the company here'.

Before becoming mayor of Prenzlau, Mr. Sommer worked as director of the economic administration of Prenzlau. In this position, he was able to establish strong ties to leading directors of many companies from the region. This social capital is demonstrated by the following statement: 'I have the phone numbers of all directors of companies in the renewable energy sector saved on my mobile. If they have something that must be done, say an ugly spot or they need a sign for their company replaced they can give me a call. They know they can rely on me. The thing will be fixed - rather by ten o'clock than noon as it was promised. (...) I have a good relation to the prime minister and some other ministries on the federal state level. This is no guarantee for everything-working-out-fine but it comes in handy from time to time'.

The city of Prenzlau actively supports a favourable environment for renewable energy projects. A special fund to financially support private solar installations and a support for a citizen-owned solar system are just some of the most visible attempts. These efforts are justified by Mr. Sommer by referring to climate change: 'As a small city, we have to contribute as we can'. and by pointing out that this transformation brings about some advantages for the city: 'First of all, it's good for the image. Then it's the fastest growing industrial sector. We got more than 1,000 jobs in the last years'. Thirdly, there is the aspect of regional value creation. A further driver in the context of Prenzlau is the clear vision by the mayor of how the city is to develop in the coming years in terms of renewable energy. Such a vision was not found for the other two cases.

The attitude by Mr. Sommer towards the environment in general and climate change in particular shaped this vision. Mr. Sommer perceives himself as a person concerned about 'the environment'. When asked about a special moment that triggered this attitude, Mr. Sommer replies, 'My hobby is fishing. (...) I see the consequences of climate change first-hand. If I set up my tent at the shore of a lake in this region, I know that some 10 to 20 years ago, I would have been in deep water at exact that spot'. These observations are confirmed by several studies on the impact of climate change in Brandenburg [37]. According to the Potsdam Institute for Climate Impact Research, Brandenburg will have to face a drastic reduction of annual precipitation. Especially vulnerable are open stretches of water [38].

These impressions are accompanied by a negative perception of fossil fuels. Mr. Sommer names expected price increases, independence, having the decision power about the future of energy supply in Prenzlau - including investment decisions - as important factors. When asked for his vision of how the city should look like in the mid-term and the long-term, he answered, 'In the mid-term, I hope for no more use of fossil fuels in Prenzlau except for the transport sector. Then I hope that we have a geothermal plant running that produces heat and electricity and furthermore I hope for a greater acceptance of renewable energy by the population. For the long run, I envision car use based on fuel cells and maybe one day, the region will supply big cities like Stettin or Berlin with energy'.

The development of the last years and the implementation of the vision into local politics have created a favourable environment for renewable energy. The city has set up a fund to support renewable energy projects within the city limits. A decision was taken by the city parliament to publicly claim the title 'City of Renewable Energy'. As a consequence, Prenzlau advertises its outstanding portfolio in the field of renewable energy across Germany. Furthermore, several aspects of supporting renewable energy have been mainstreamed in the city decisionmaking processes. This favourable political environment is backed up by two more structural factors. Prenzlau has optimal conditions for the generation of renewable energy. The agency for renewable energy indicates that the region around Prenzlau has excellent wind conditions. Furthermore, hot salt brine runs under the city. Three blast holes that have been drilled before 1989 can now be used for potential geothermal energy generation (see Figure 5).

\section{Case 3: Feldheim (Treuenbrietzen)}

The village of Feldheim is a unique showcase for local renewable energy. This is the result of a process that was initiated some 17 years ago when Energiequelle approached the municipality to set up the first wind turbines in 1996. Mr. Knape states, 'I compared our case with Güssing in Austria and Übigau-Wahrenbrück and was surprised to see that they started with a clear concept and went for it. Here, on the other hand, one led to another and we had a development that lasted 


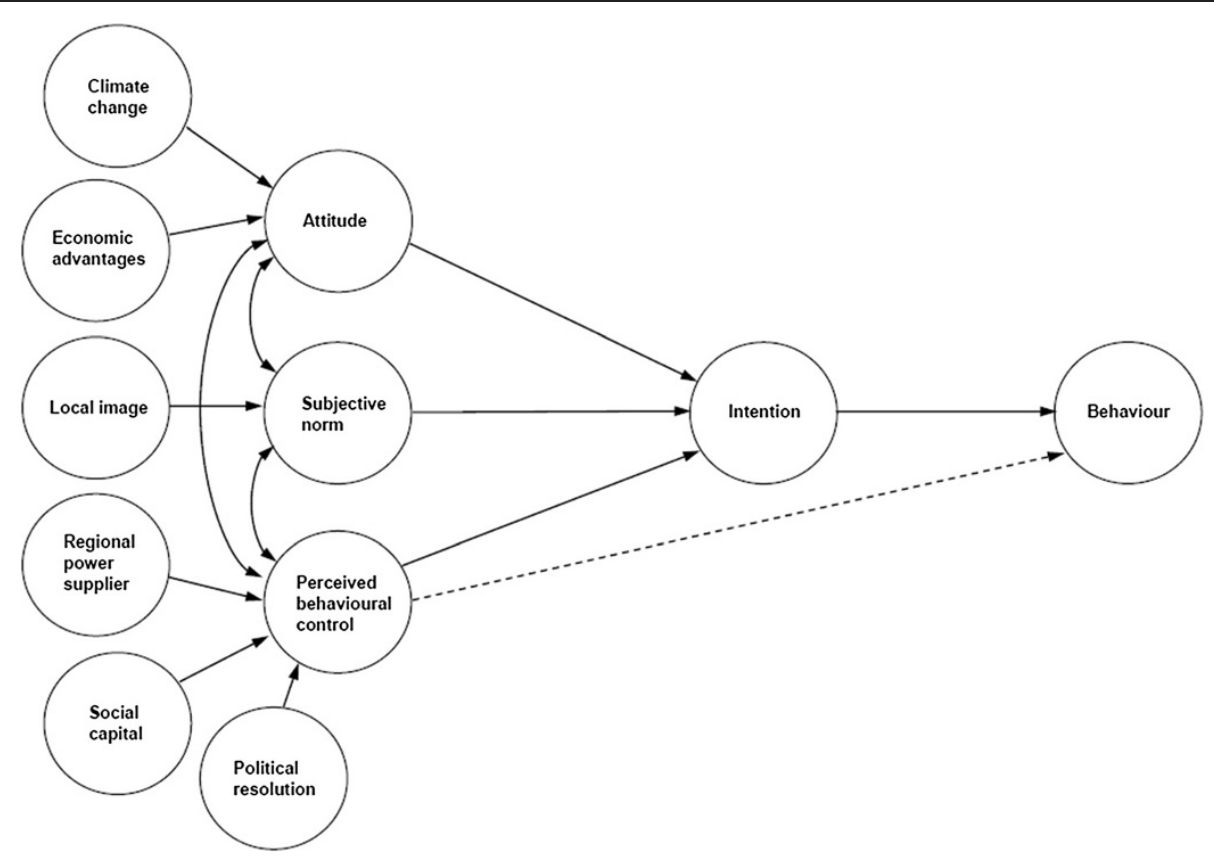

Figure 5 Theory of planned behaviour for Mr. Sommer.

several years and nothing was planned'. Not only did the municipality not have a clear vision, but also the investor did not have one either. Instead, there was a process of evolution towards renewable energy. As described by Mr. Knape, this process stands in stark contrast to the named cases of Güssing in Austria [39] or Übigau-Wahrenbrück in Brandenburg [40].

The key actors in this process were identified as the village council of Feldheim, the directors of Energiequelle, the responsible regional planning authority and from 2002 onwards, Mr. Knape as mayor of Treuenbrietzen, and after the project turned out to be successful and became a show case, several ministries took on an active role in supporting the project. In this context, a further key actor includes the people of Feldheim who can be considered too, because of their great contribution to the project. Because many decision-making processes of this population take place in institutionalized ways (local parliaments or by delegating decision-making power to elected representatives) the community is considered to be an actor. Feldheim Energie was founded to expand the available scope of action. It is a limited partnership that was formed by the households connected to the heat grid, the municipality and enterprises involved in the project. It constitutes a legally responsible actor who is capable of action and who is based in the village while at the same time guaranteeing a strong sense of ownership to the involved households.

A decisive factor for the development in Feldheim was social capital. The following statements demonstrate a need to categorize different kinds of social capital because they influenced the process on different levels. First, Energiequelle tried to build up social capital by contributing to the social life in Feldheim. Mr. Knape stated, 'At some point, it was about market economy and at some point it was about social marketing. But there was no 'deal' in the sense that Energiequelle offered something in advance'. Second, social capital played a role in the internal decision-making processes of the community. Mr. Knape stated, 'While Feldheim only has about 200 inhabitants, there are more than 200 signed-up memberships in local clubs. (...) They have a very active social life in the village'. And third, there is the social capital between (individual) key actors, which is demonstrated by mentioning several times by Mr. Knape, that the process took place in close cooperation.

The advantages for Feldheim are obvious. First of all, the efforts taken by Energiequelle must be named. These ranged from financing a village fête to sanitation of streets and side-walks, to new flood lighting for the local football pitch. Then there are the four aspects Mr. Knape named as jobs, reliable energy prices, social life in the village and addressing climate change. Maintenance of the local installations provides permanent jobs directly. Long-term contracts were struck between Feldheim Energie and local agricultural businesses which provide substrate for the biogas plant. The inhabitants of Feldheim have long-term contracts with Feldheim Energie - the company they partly own themselves. This constellation guarantees stabile and low prices. The commonly shared 
ownership of the energy installations strengthens the sense of common responsibility. According to Mr. Knape, this has had positive impacts on social cohesion and local identity. Furthermore, the new energy system helps to curb greenhouse gas emissions attributed to the inhabitants of Feldheim. Lastly, the factor of regional value creation has to be mentioned as the energy company is connected to the municipality, funds remain within the local value web.

When it comes to structural factors, Feldheim has less to offer than the cases of Prenzlau or Turnow-Preilack. Admittedly, Feldheim has good conditions for wind power production and was therefore identified by the regional planning authorities (Regionales Planungsamt) for further wind turbine installations. Except for that, no further pre-existing structural factors were identified. On the contrary, the project in Feldheim even shaped its own structural conditions. This might sound contradictory in the beginning but becomes clearer if a second look at the legal processes is taken. Some of the installations in Feldheim (e.g. batteries for emergency power supply) were cutting-edge technology at the time of project implementation. The same was valid for questions of ownership structure or the obligation for the Federal Government to provide services for the public. As no law is available, the case of Feldheim forced the Federal Government to issue directives to provide the needed legal framework (see Figure 6).

\section{Discussion}

In the following section, each of the identified factors in the decision-making processes of the mayors is discussed. Links between observations during the field work and relevant literature are established. The theory of planned behaviour is used to ascribe the different aspects into the categories of 'Attitude', 'Subjective norm' and 'Perceived behavioural control' (see Table 2). As mentioned above, 'Attitude' and 'Subjective norm' are referring to the aspects that directly drive the intentions of actors. 'Perceived behavioural control' also influences intentions of people but it also defines the perceived range of what can be achieved. Therefore, the factors that influence this category include conditions outside the attitude of the mayors. For example, the existence of a regional power supplier under the control of the municipality may increase the range of possible actions for a mayor while not directly influencing attitudes towards these measures. Likewise, a high social cohesion within a municipality might make the implementation of demanding projects possible and might provide favourable conditions that increase the range of options for mayors.

\section{Climate change}

A surprising finding of this research was that climate change only played a minor role in the decision-making process of the key actors. While it creates favourable structures through its influence on higher administrative levels (e.g. availability of funding), its impact on individual decision making seems to be rather marginal. Only Mr. Sommer linked climate change to the introduction of renewable energy. He perceived his efforts to support renewable energy installations as a measure to mitigate climate change. Nevertheless, it should be noted that all three mayors expressed their concern about climate change when asked directly. It can be argued that a discrepancy between behaviour and attitude can partly be explained by the lack of tangible experience that would link behaviour to attitude [41].

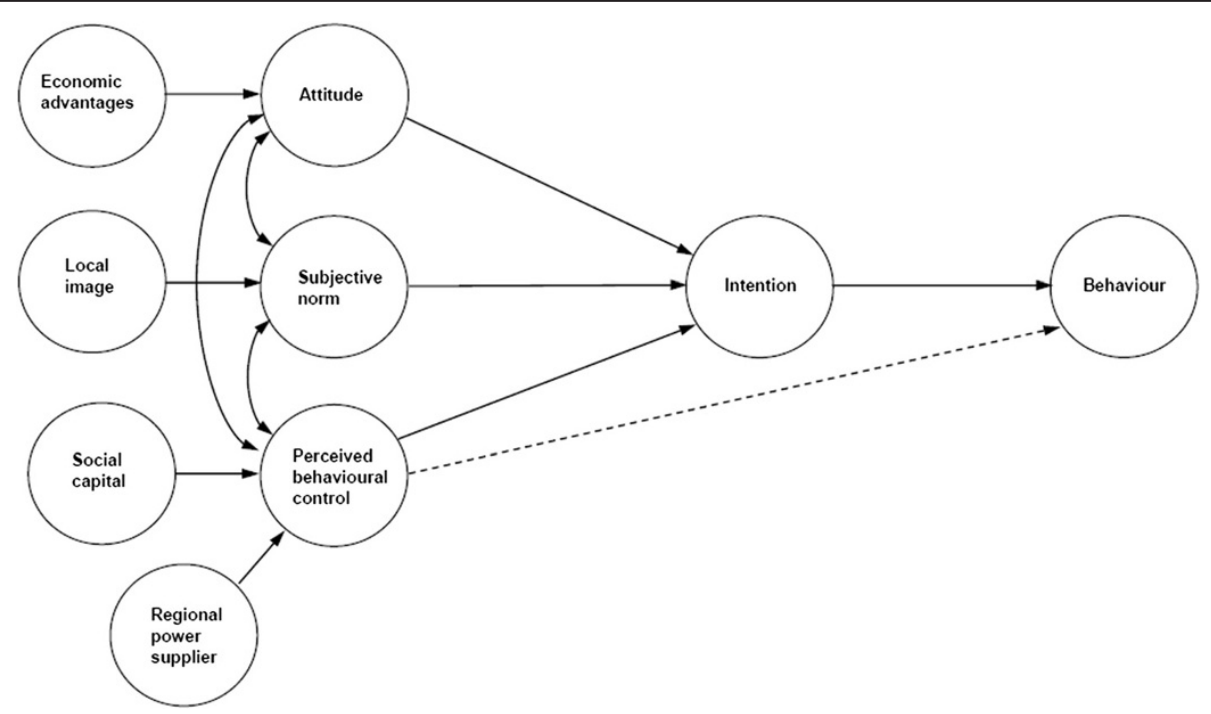

Figure 6 Theory of planned behaviour for Mr. Knape. 


\begin{tabular}{ll}
$\begin{array}{l}\text { Table } \mathbf{2} \text { Key factors categorised according to theory of } \\
\text { planned behaviour }\end{array}$ \\
\hline Key factors & Direct influences \\
\hline Climate change & Attitude \\
Economic advantages & Attitude \\
Local image (including regional & Subjective norm \\
value creation) & \\
Social capital & Perceived behavioural control \\
Political resolutions & Subjective norm and perceived \\
& behavioural control \\
Regional power suppliers & Perceived behavioural control \\
Enthusiasm for technology & Attitude \\
(including expert knowledge) &
\end{tabular}

Therefore, it is relevant to explore the experiences of key actors linked to the environment. Mr. Sommer connected his perception of climate change to his individual experience of fishing. He also put his experience of environmental change into the context of public discussions about climate change. Mr. Fries, on the other hand, did not mention any individual perception linked to climate change. Furthermore, he pointed out that the decision to support the installation in Turnow-Preilack was not at all influenced by climate change. However, he labelled the solar power plant as 'clean energy' that - in his opinion - stands in stark contrast to the 'dirty energy' from the nearby Jänschwalde coal power plant. For Mr. Knape, the findings are similar. Climate change mitigation was only mentioned as a positive 'side effect' of the development in Feldheim that did not significantly influence the ex-ante decision making of any of the involved actors.

These findings, which present climate change as a 'minor' driver, are even more surprising if compared with initiatives such as the Covenant of Mayors or the Climate Alliance which explicitly place the actions of municipalities into the context of climate change mitigation (and adaptation) efforts. Initiatives like the Covenant of Mayors or grass root groups did not have a (positive) impact on the development of renewable energy in any of the three cases. Research has shown that many municipalities all over Europe actually join these networks to make a difference in the combat against climate change [42].

Chawla [43] states that 'environmental sensitivity' is often shaped by a number of factors. As the most important of these factors, Chawla mentions the 'childhood experience of nature' [43]. Therefore, the engagement by Mr. Sommer in renewable energy might be partly explained by an overall 'pro-environmental' behaviour linked to his experiences of fishing from early childhood. While climate change remains an overarching issue that provides the foundation for establishing legitimacy for expanding renewable energy, it only plays a minor role in the investigated decisionmaking processes. The case of Mr. Sommer suggests that it can be worthwhile to investigate the experiences and lives of key actors on a deeper level to uncover reasons for environmentally sound behaviour.

\section{Economic advantages}

Three economic advantages directly connected to the introduction of renewable energy were identified in the case studies. Firstly, all the renewable energy projects have created and secured permanent jobs in different branches. Put simply, a solar plant must be maintained and guarded and a nature reserve must be managed (Turnow-Preilack), thus creating new jobs. The biogas plant in Feldheim must be fed with substrate. Long-term contracts with nearby farms secure jobs in the long run, as does a plant producing components for solar panels which was built in Feldheim by Energiequelle. These local lessons are in line with the overall development in Germany. An estimated 340,000 jobs in Germany are directly related to the renewable energy industry [44].

Secondly, renewable energy offers a possibility to cut costs in the long run. In regions without access to district heating grids the heating of buildings is still often done by burning fossil fuels. This is particularly true for rural areas in Eastern Germany [9]. In many cases, the costs for heating can be considerably reduced if a switch from coal and oil to, for example, biogas is undertaken. If public buildings such as community centres can be heated with renewable appliances, considerable cost cutting can be achieved. The third factor that directly links the municipality economically to renewable energy is the due tax. Producers of electricity are paid for feeding into the grid. If this income exceeds a certain amount, producers have to pay a local business tax. This tax is an important income for municipalities.

All three economic factors (jobs, savings and taxes) add to the regional value creation, because capital stays within the borders of the municipalities and is (potentially) reinvested locally. Regional value creation is defined as 'a measure for productive economic activity. It is made up by the difference of the value of a unit of production and the value of the consumed pre-product' [45]. Regional value creation was a very relevant argument for the implementation of the projects. Economic advantages are a crucial precondition for the success of renewable energy projects. The investigated projects paid out financially for the municipalities. This fact is reflected in the positive ex-post evaluation of the development by the municipal key actors. The Wuppertal Institute came to similar findings and states that 'regional value creation can be central motivation for the expansion of renewable energy' ([45], p.30). 


\section{Local image}

A recurring theme in the interviews was local image. All three mayors perceive renewable energy as beneficial for local image. The positive image of renewable energy can be found in three main aspects. First, the efforts of the municipality can be placed in the narrative of the national transition towards $100 \%$ renewable energy. Spearheading this development can be considered positive. Second, the mayors see the renewable energy industry as innovative, technologically progressive and very human-capital intense. It is therefore perceived as something new, 'modern' and, therefore, desirable. Third, fostering renewable energy is publicly perceived as something that is 'good for the environment'. While climate change, as such, did not seem to have a significant influence on the projects analyzed here, climate change appears to gain influence through the 'catalyst' of local image creation.

Alvesson differentiates between two different functions of image, internal 'for the agent's own sake' and external for shaping a 'sender-audience' relationship. These findings are not only relevant for companies (knowledge-intense firms), but also for 'organizations that are knowledge intensive' and that 'revolve around the use of intellectual and analytical tasks' [46]. Placing a municipality in this framework requires some adjustments. While the work of a municipal administration is indeed dominated by 'intellectual and analytical tasks', it is still decisive for the development of a municipality as a whole (with all its social and physical entities) and (hopefully) works for the good of all its citizens. When comparing the municipal administration with a company, one could say that the mayor represents the chief executive officer, the municipal staff is the board of directors and the remaining entities within the borders of the municipality are the other departments of a company. This comparison is necessary to understand at whom an image is directed.

The function of 'for the agent's own sake' can be seen in the desire of mayors to be re-elected and to sharpen their personal profile (identity) and of the administration to be supported by the local citizens. Furthermore, the members of the administrative staff are often inhabitants of the municipality themselves. Thus, this shaping of identity spreads beyond the administrative staff to the whole municipality. The second function of image is relevant for companies to strengthen their 'market position'. Alvesson ([46], p.71) states, 'Image in this sense plays an increasing role in organizations and economic life, primarily in the way that customers and other external actors view an organization'.

This now raises the question of how municipalities fit into this whole market competition scheme. Anderberg and Clark argue, 'A positive image of a city or region attracts people, investors and enterprises. High-quality environment and local sustainability initiatives can be used for creating a positive image. A growing number of regions and cities around the world have in recent years attempted to exploit this opportunity through sustainable development strategies and innovative environmental initiatives combined with green image marketing' ([47], p.591). It follows that municipalities compete for attracting residents, companies and visitors but also for the goodwill of higher-ranking administrations. Mr. Fries says, 'We have many visitors for the power plant. Last week, I even got a call from a Taiwanese TV station. The people have to stay somewhere and have to eat'. The desire to institutionalize local image culminated in the plans of both Mr. Knape and Mr. Fries to install a centre for competencies in renewable energy within their respective municipality.

A further positive aspect of having a well-known project was identified by Mr. Knape who says, 'We experienced a further development of the project by people who visited the site and made suggestions of how to improve the project'. However, Mr. Knape also states, 'Image did not play any role in the initial phase of the project. But in the ex-post evaluation, it becomes interesting. The problem with image is that it only becomes interesting, when you have the capacities to live up to it. We need somebody to deal with all this information demand from outside.' Although image did not seem to play a role in the initial processes, it is still a valid argument for other municipalities that are about to implement projects in the field of renewable energy.

\section{Social capital}

Social capital played a decisive role in two of the investigated cases: Feldheim and Prenzlau. Since social capital manifested in very different forms and on different levels of investigation, a further differentiation of the concept is needed. Glanville and Bienenstock argue that 'most authors agree that social capital refers to investment in personal relationships or social structure that facilitates the achievement of individual or collective goals' ([48], p. 1507). Consequently, 'investment in interpersonal relationships is what creates social capital' ([48], p.1509). Although contested in the academic discussion, social capital as a concept is used here to explain the phenomena on the micro and the macro levels. The three different observed manifestations of social capital include between key actors (micro), between a single key actor and a community (micro and macro), and the social capital within a group (macro).

The first form of social capital is rather unproblematic. It takes place on the micro level and describes the degree of trust and reciprocity between two individuals. It works as a resource that can be positive or negative for a specific goal attainment [49]. Despite the theoretical 
possibility of the occurrence of social capital with negative impacts on renewable energy projects (e.g. one could imagine a mayor being influenced by a friend who is a radical wind energy opponent), social capital between key actors was only found to have positive impacts on the spread of renewable energy in the investigated case studies. Of special interest in this context is the social capital connected to Mr. Sommer who seems to constitute a hub for social capital to key actors from the renewable energy branch.

The second kind of social capital (between key actors and a community) is more difficult to grasp. It can be questioned whether the relationship between the people of Feldheim and Energiequelle can really be called social capital. Here, it is argued that it actually constitutes a form of social capital, because it builds on trust and reciprocity without relying on legal tools - like formalised contracts - for the enforcement of this reciprocity. The complicating aspect is that this kind of social capital belongs to both the micro level and the macro level. While every individual of Feldheim builds trust towards Energiequelle or its director, Energiequelle only builds trust towards 'the people of Feldheim' in their entirety.

The third form of social capital is made up by the sum of all social capital between the people of Feldheim and therefore it is to be found on the macro level. The analysis of all of these single connections is outside the scope of this research as the level of reference is the whole village. What is relevant for this research is that this 'diffused' social capital within the population of the village has a significant effect on the collective decision-making processes. However, this kind of social capital can have negative consequences for renewable energy; a well-organized resistance group could severely disrupt an implementation process. Even if not observed in the investigated cases, groups like 'Rettet die Uckermark' (Save the Uckermark) have decisively inhibited renewable energy projects all over Brandenburg in the name of landscape preservation.

\section{Political resolutions}

Mårtensson and Westerberg stress the importance of a strategy for a successful implementation of bioenergy systems in municipalities [50]. A strategy must be based on a vision and backed-up by a political resolution. Khan argues that single investments should be placed in the broader context of a coherent development [51]. These findings from the Swedish context are confirmed for the German context by deENet [8]. They found that $80 \%$ of the investigated regions and municipalities had a political resolution to switch to renewable energy or were at least planning to issue such a resolution. However, it seems that for the investigated cases in this paper, strategies, visions and political declarations of intent are ex-post products of a successful renewable energy implementation process rather than an initial driver.

A published strategy was not found for any of the cases. Instead, Mr. Sommer and Mr. Knape pointed out that the processes grew and were not envisioned from beginning to end. A clear vision for the future was formulated by Mr. Sommer; however, it must be questioned to what extent this vision had an influence on the development or if the vision simply reflects positive experiences with renewable energy projects. In Feldheim, Mr. Knape explicitly said that no vision was involved at all. For political resolutions, the situations look similar. While the institutions in Prenzlau made their pro-renewable energy resolutions for future projects, Treuenbrietzen does not have such a political resolution. According to Mr. Sommer, the political resolution of Prenzlau did simplify decision-making processes. Political resolutions can serve as directions in individual decisionmaking processes by mayors; justifying a pro-renewable energy decision is much easier when relying on resolutions that have been approved by other political bodies within the municipality. Resolutions also serve as a basis on which to mainstream the decision making of other administrative bodies within municipalities. They can also serve as a 'constant reminder' whenever democratic processes are involved.

\section{Regional power suppliers}

Municipal-owned regional power suppliers are a central element for municipalities in Germany to actively foster renewable energy. In two of the three cases that were investigated in this research, the regional power suppliers play a major role. In the case of Prenzlau, the supplier contributes by applying innovative practices and by effectively using the available potentials (e.g. biogas from waste water sludge and geothermal power). By owning the Stadtwerke Prenzlau, the city keeps the ability to direct investments and to make decisions towards a sustainable transition of the local energy system. Furthermore, the company staff holds the human capital necessary for innovative projects. For the case of Feldheim, the founding of a new energy company was necessary to implement the renewable energy plans. The ownership structure of this company differs considerably from that in Prenzlau. The energy company of Feldheim is owned by the citizens of the village. This was necessary to raise the needed capital.

Kunze and Busch found that this approach of founding a local energy company provides a number of advantages [9]. Distributed ownership can considerably lower resistance against energy projects as a result of two main factors. Firstly, by involving potential opponents in the decision-making process, conflicts can be addressed and resolved in the initial phase of the project; and 
secondly, if profits are redistributed amongst the local population, resistance tends to be much lower, since individual economic benefits are linked to the success of the project. However, this kind of organization comes with a very high level of social complexity. In the case of Feldheim, where such an arrangement has been made, the process of trust building, both between actors and in the technology, took several years while relying on already available high levels of social capital within the village [9].

\section{Enthusiasm for technology}

Enthusiasm for renewable energy technology has been identified as a factor that positively influences the introduction of renewable energy. A concrete example was named by Mr. Knape who stated, 'Our former director of the regional administration had worked in the energy sector. His understanding, interest and enthusiasm in the whole thing were bigger. Our new one comes from the humanities and I have to explain everything to him'. While technical knowledge and enthusiasm are actually two different possible drivers, they were always named together in the investigated cases. The role of expert knowledge within the municipality is obvious for the case of Prenzlau. Here, the main tool for implementing the ambitious energy projects was the high human capital within the regional power supplier. The Stadtwerke Prenzlau thus served as a place with accumulated expert knowledge that could be put to use if a new project was to be developed.

In Feldheim, expert knowledge also played a very important role [9]. However, this knowledge was not centred within one entity but distributed among the inhabitants [9]. Experts of a particular field - who as a consequence of their status as friend and neighbour were equipped with a high social capital within the municipality - undertook the task of evaluating specific aspects of the projects. For example, a local insurance broker verified the fairness of the contracts while inhabitants with technical schooling approved of appliances and helped explain technical aspects to other inhabitants. Thus, diffused expert knowledge in combination with high levels of trust within the local population, helped to overcome scepticism that built on ignorance and mistrust. While this process is interesting from a sociological point of view neither enthusiasm for technology nor expert knowledge were major factors for the individual decision-making process of the interviewed mayors.

\section{Conclusions}

While remaining an underdeveloped research field, the individual decision-making processes of mayors to support renewable energy projects has shown to be of great importance for the investigated cases. These cases can be seen as models for a general transition of energy supply in Germany (and Europe). By identifying a number of relevant factors influencing this individual decision-making process, this research has aimed to shed more light on how and why municipalities implement renewable energy projects. In conclusion, there are at least three topics that can be highlighted from this research. First, the overall theme regularly cited by interviewed actors as the 'good of the municipality'. Second, the key lessons for promoting renewable energy to local municipalities. Third, there were several issues that deserve further research attention.

\section{Overall theme}

In the course of this research, several drivers have been identified. It was hard to clearly distinguish between some of them. This problem can be traced back to the fact that one dominating theme was the basis for action of mayors. They ultimately focus on the 'good of the municipality'. More abstract aspects such as 'climate change' or 'the transformation of the German power supply system' only played a minor role. Especially climate change had a surprisingly low relevance for the interviewed actors. Mr. Sommer was the only mayor who directly addressed climate change and who linked the renewable energy projects in Prenzlau with concrete climate change projections for Brandenburg.

The 'good of the municipality' can be understood as the utility of the inhabitants. It is defined by economic factors such as jobs, income or tax revenues that are used to finance civil services. However, this narrow definition does not encompass the relevant non-economic aspects. The strengthening of social life, the absence of a health hazard or an experience of progress can be important - and sometimes even sufficient - reasons for renewable energy and must therefore be added to the 'good of the municipality'. Renewable energy projects do not have to provide huge financial benefits to be approved by the local population. Sometimes it is sufficient for people to see that 'something positive is happening'.

\section{Key lessons}

This research suggests that initiatives promoting renewable energy to municipalities should focus on the tangible advantages for municipalities, instead of spending resources on explaining and promoting the 'fight' against climate change. The only global factor that should be included is the depletion of fossil fuels and the resulting projections about energy prices since this directly impacts municipalities. Information should furthermore include concrete suggestions of how municipalities can deal with limiting factors such as financial constraints or a lack of know-how when investing in renewable energy. Here, regional power 
suppliers can play a major role. Positive examples should be further stressed to demonstrate what possible courses of action are available.

The compensation for or internalization of externalities has to be taken into account. Municipalities need to not only contribute to renewable energy but also contribute to everybody profiting from them and if necessary reject projects with unbalanced outcomes, because one negative project may destroy the chance for many other positive projects. The examples of Feldheim and Prenzlau have shown that different (indirect) ways of compensating for an obstructed view or blocked forest trails are possible. Finally, all mayors reported a great interest in the renewable energy projects by other municipalities. Initiatives that allow the exchange of experiences and knowledge between mayors and staff at the municipal level should be encouraged.

A number of relevant lessons can be learned by other (small) municipalities that plan to aim for $100 \%$ renewable energy. The most important is that instead of focussing on the obstructions that have to be overcome in energy transitions, mayors and other key actors should focus on the drivers and possibilities present in the community. Another important lesson for initiators of local energy transitions is that abstract aspects like climate change or the nationwide energy transition play a very minor role. However, positive local impacts can be observed in the investigated success cases. These impacts and their contribution to 'the good of the municipality' should be highlighted in future transition processes.

\section{Further research}

In the process of conducting this research, three themes emerged that could not be explored further in the scope of this research. The themes are responsibility to children, the 'paradox of the greens', and access to capital. While not being explicitly mentioned in any of the three cases, responsibility towards children might be an additional factor to play into a decision-making process. All three mayors have children. Not only did this factor not occur in the data generated for this research, but it is also hard to categorize. Parenthood might indeed have a positive correlation with the investigated behaviour. Responsibility towards children might work as a strengthening factor underlying other drivers. Scope and availability of data in this research are not sufficient to produce more than speculations. However, this issue seems to remain relevant.

A theme that came up in the case studies was a phenomenon that can be called the 'paradox of the greens'. While the Green Party paved the way for the implementation of renewable energy during their government with the Social Democrat Party (1998 to 2005), it seems that on the local level, 'greens' can have the reputation of being the greatest opponents to renewable energy projects (as a promoter of strict nature conservation). This may be due to the very heterogeneous groups that initially founded the Green Party. It furthermore should be noted that the German 'greens' do not wield extensive political power in the countryside of Brandenburg in Germany. None of the interviewed mayors is a member of the Green Party.

When renewable energy projects are implemented within the borders of a municipality the question of who finances the project must be asked. The three cases have demonstrated three different ways. In Prenzlau, the invested capital was raised by the municipal-owned Stadtwerke, in Turnow-Preilack an external investor provided the funds, and in Feldheim (besides the investments by Energiequelle), the capital was mobilized by making the citizens investors. However, the access to capital provided by other institutions (national and European Union funds) can be a decisive factor. The investigated cases show that if a strong will to implement a project is present, capital can be acquired in different and creative ways.

\section{Competing interests}

The authors declare that they have no competing interests.

\section{Authors' contributions}

$\mathrm{HB}$ and $\mathrm{KMCC}$ designed the study and methodology. HB carried out the fieldwork and drafted the initial manuscript. HB and KMCC edited the manuscript. Both authors read and approved the final manuscript.

\section{Authors' information}

$\mathrm{HB}$ is a Doctoral Candidate in Sustainability Science at the Lund University Centre for Sustainability Studies (LUCSUS) and the Lund University Centre of Excellence for Integration of Social and Natural Dimensions of Sustainability (LUCID) in Sweden. His background is in governmental studies with a focus on economics and in sustainability science. He works on local responses to climate change and renewable energy. $\mathrm{KMcC}$ is an Assistant Professor at the International Institute for Industrial Environmental Economics (IIIEE) at Lund University in Sweden. Broadly speaking, he works in the fields of sustainability and governance. More specifically, he concentrates on exploring the implementation of renewable energy and bioenergy systems, investigating key drivers and barriers as well as experiences of supportive (and disruptive) policies and actions. His background is in environmental studies and politics.

\section{Author details}

'Lund University Centre for Sustainability Studies (LUCSUS), P.O. Box 170, 22100 Lund, Sweden. ${ }^{2}$ International Institute for Industrial Environmental Economics (IIIEE) at Lund University, P.O. Box 196, 22100 Lund, Sweden.

Received: 23 August 2013 Accepted: 3 February 2014 Published: 5 March 2014

\section{References}

1. Mathiesen BV, Lund H, Karlsson K (2011) 100\% Renewable energy systems, climate mitigation and economic growth. Appl Energy 88:488-501, doi:10.1016/j.apenergy.2010.03.001

2. Lund H, Mathiesen BV (2009) Energy system analysis of $100 \%$ renewable energy systems - the case of Denmark in years 2030 and 2050. Energy 34:524-531, doi:10.1016/j.energy.2008.04.003

3. Lund H, Østergaard PA, Stadler I (2011) Towards 100\% renewable energy systems. Appl Energy 88:419-421, doi:10.1016/j.apenergy.2010.10.013 
4. Glasnovic Z, Margeta J (2011) Vision of total renewable electricity scenario. Renew Sustain Energy Rev 15:1873-1884, doi:10.1016/j.rser.2010.12.016

5. Sachverständigenrat für Umweltfragen (SRU) (2011) Wege zur 100\% erneuerbaren Stromversorgung., p 390

6. DeENet eV (2013) Hessen aktiv: 100 Kommunen für den Klimaschutz., http://www.deenet.org/projekte/100-kommunen-fuer-den-klimaschutz/. Accessed 21 Jan 2013

7. Wüste A, Schmuck P (2012) Bioenergy villages and regions in Germany: an interview study with initiators of communal bioenergy projects on the success factors for restructuring the energy supply of the community. Sustainability 4:244-256, doi:10.3390/su4020244

8. Projekt 100\%-Erneuerbare-Energie-Regionen (2009) Schriftliche Befragung von Erneuerbare-Energie-Regionen in Deutschland- Regionale Ziele, Aktivitäten und Einschätzungen in Bezug auf 100\% Erneuerbare Energie in Regionen. deENet Geschäftsstelle, Kassel

9. Kunze C, Busch H (2011) The social complexity of renewable energy production in the countryside. Electron Green J 1:1-18

10. Kern K, Bulkeley H (2009) Cities, Europeanization and multi-level governance: governing climate change through transnational municipal networks. JCMS J Common Mark Stud 47:309-332, doi:10.1111/j.1468-5965.2009.00806.x

11. Späth P, Rohracher H (2013) Beyond localism: the spatial scale and scaling in energy transitions. In: Scale-sensitive governance of the environment. Edited volume. Wiley, Oxford, in press

12. Betsill M, Bulkeley $H$ (2006) Cities and the multilevel governance of global climate change. Glob Gov 12:141-159

13. Janicke M (2008) Ecological modernisation: new perspectives. J Clean Prod 16:557-565, doi:10.1016/j.jclepro.2007.02.011

14. Barrutia JM, Echebarria C, Hartmann P, Apaolaza-lbáñez V (2013) Municipal managers' engagement in multi-level governance arrangements: an empirical analysis grounded in relational economic geography. Geoforum 50:76-87, doi:10.1016/j.geoforum.2013.08.003

15. Newig J, Fritsch $O$ (2009) Environmental governance: participatory, multilevel - and effective? Environ Policy Gov 19:197-214, doi:10.1002/eet.509

16. McCormick K (2007) Advancing Bioenergy in Europe: exploring bioenergy systems and socio-political issues. Lund University, Dissertation

17. McCormick K, Kåberger T (2005) Exploring a pioneering bioenergy system: the case of enköping in Sweden. J Clean Prod 13:1003-1014

18. Walker G, Cass N (2007) Carbon reduction, "the public" and renewable energy: engaging with socio-technical configurations. Area 39:458-469, doi:10.1111/j.1475-4762.2007.00772.x

19. Walker G, Hunter S, Devine-Wright P, Evans B, Fay H (2007) Harnessing community energies: explaining and evaluating community-based localism in renewable energy policy in the UK. Glob Environ Polit 7:64-82, doi:10.1162/glep.2007.7.2.64

20. Kunze C (2012) Soziologie der Energiewende. bidem-Verlag, Stuttgart, p 188

21. Sovacool BK (2009) The cultural barriers to renewable energy and energy efficiency in the United States. Technol Soc 31:365-373, doi:10.1016/j. techsoc.2009.10.009

22. Mccormick K, Kaberger T (2007) Key barriers for bioenergy in Europe: economic conditions, know-how and institutional capacity, and supply chain co-ordination. Biomass Bioenergy 31:443-452, doi:10.1016/j. biombioe.2007.01.008

23. Pasqualetti MJ (2011) Social barriers to renewable energy landscapes*. Geogr Rev doi 101:201-223, doi:101:201-223, 10.1111/j.1931-0846.2011.00087.x

24. Silverman D (2005) Doing Qualitative Research, 2nd edn. Sage Publications, London

25. Flyvbjerg B (2011) Case Study. In: Denzin NK, Lincoln YS (eds) Sage Handb. Qual. Res, 4th edn. Sage Publications, Thousand Oaks, CA, pp 301-316

26. Jerneck A, Olsson L (2013) Food first! Theorising assets and actors in agroforestry: risk evaders, opportunity seekers and "the food imperative" in sub-Saharan Africa. Int J Agric Sustain, doi: 10.1080/14735903.2012.751714

27. Ajzen I (1988) Attitudes, personality, and behavior. The Dorsey Press, Chicago

28. Ajzen I (1991) The theory of planned behavior. Organ Behav Hum Decis Process 50(2):179-211

29. Armitage CJ, Conner M (1999) The theory of planned behaviour: assessment of predictive validity and 'perceived' control. Br J Soc Psychol 38:35-54, doi: 10.1348/014466699164022

30. Loewenstein GF, Weber EU, Hsee CK, Welch N (2001) Risk as feelings. Psychol Bull 127:267-286, doi: 10.1037//0033-2909.127.2.267
31. Han H, Hsu L-T(J), Sheu C (2010) Application of the theory of planned behavior to green hotel choice: testing the effect of environmental friendly activities. Tour Manag 31:325-334, 10.1016/j.tourman.2009.03.013

32. Fielding KS, McDonald R, Louis WR (2008) Theory of planned behaviour, identity and intentions to engage in environmental activism. J Environ Psychol 28:318-326, doi: 10.1016/j.jenvp.2008.03.003

33. Steg L, Vlek C (2009) Encouraging pro-environmental behaviour: an integrative review and research agenda. J Environ Psychol 29:309-317, doi: 10.1016/j. jenvp.2008.10.004

34. Hargreaves T (2011) Practice-ing behaviour change: applying social practice theory to pro-environmental behaviour change. J Consum Cult 11:79-99, doi: $10.1177 / 1469540510390500$

35. Charmaz K (2006) Constructing Grounded Theory, 1st edn. SAGE Publications, London

36. Juwi Solar, First Solar (2009) Lieberose Solar Park - an environmental showpiece. http://www.solaripedia.com/files/242.pdf

37. Linke C, Grimmert S, Hartmann I, Reinhardt K (2010) Auswertung regionaler Klimamodelle für das Land Brandenburg - Darstellung klimatologischer Parameter mit Hilfe vier regionaler Klimamodelle (CLM, REMO, WETTREG und STAR) für das 21. Jahrhundert. Fachbeiträge des Landesumweltamtes Heft Nr. 113 Landesumweltamt Brandenburg, Potsdam, Germany

38. Gerstengarbe F, Badeck F, Hattermann F, Krysanova V, Lahmer W, Lasch P, Stock M, Suckow F, Wechsung F, Werner PC (2003) Klimatischen Entwicklung im Land Brandenburg bis 2055 und deren Auswirkungen auf den Wasserhaushalt, die Forst-und Landwirtschaft sowie die Ableitung erster Perspektiven. Potsdam-Institut für Klimafolgenforschung (PIK), Potsdam

39. Stadtgemeinde Güssing official homepage (2013) Stadtgemeinde Güssing. Güssing, Austria, http://www.guessing.co.at/. Accessed 22 Jan 2013

40. Energieregion lausitz-spreewald (2013) energieregion lausitz-spreewald GmbH. , Cottbus, Germany, http://www.energieregion-lausitz.de/de/die_region. html. Accessed 21 Jan 2013

41. Kollmuss A, Agyeman J (2002) Mind the Gap: Why do people act environmentally and what are the barriers to pro-environmental behavior? Environmental Education Research 8(3):239-260, http://dx.doi.org/10.1080/ 13504620220145401

42. Hakelberg $L$ (2011) Governing climate change by diffusion. Freie Universität Berlin, Forschungszentrum für Umweltpolitik, Berlin

43. Chawla $L$ (1999) Life paths into effective environmental action. J Environ Educ 31:15-26

44. Lehr U, Lutz C, Edler D (2012) Green jobs? Economic impacts of renewable energy in Germany. Energy Policy 47:358-364, doi: 10.1016/j. enpol.2012.04.076

45. Fischedick I (2010) Potenziell treibende Kräfte und potenzielle Barrieren für den Ausbau erneuerbarer Energien aus integrativer Sichtweise. Wuppertal Institut für Klima, Umwelt, Energie, Wuppertal

46. Alvesson M (2004) Knowledge work and knowledge-intense firms. Oxford University Press, Oxford

47. Anderberg S, Clark E (2012) The green and sustainable Øresund region: eco-branding Copenhagen and Malmö. In: Sustainability: A Global Urban Context. Michigan State University Press, Michigan, pp 591-610

48. Glanville JL, Bienenstock EJ (2009) A typology for understanding the connections among different forms of social capital. Am Behav Sci 52:1507-1530, doi:10.1177/0002764209331524

49. Coleman J (1988) Social capital in the creation of human capital. Am J Sociol 94:95-120

50. Mårtensson K, Westerberg K (2007) How to transform local energy systems towards bioenergy? Three strategy models for transformation. Energy Policy 35:6095-6105, doi: 10.1016/j.enpol.2007.08.007

51. Khan J (2004) Local politics of renewable energy. Dissertation, Lund University

\section{doi:10.1186/2192-0567-4-5}

Cite this article as: Busch and McCormick: Local power: exploring the motivations of mayors and key success factors for local municipalities to go $100 \%$ renewable energy. Energy, Sustainability and Society 2014 4:5. 